\title{
Portals of entry and systemic localization of proliferative gill disease organisms in channel catfish Ictalurus punctatus
}

\author{
Adrien M. G. Belem*, Linda M. Pote** \\ College of Veterinary Medicine, Mississippi State University, Mississippi State, Mississippi 39762, USA
}

\begin{abstract}
Immunized rabbit serum adsorbed in live catfish was used in indirect fluorescent antibody test (IFAT) to detect developmental life stages of Henneguya ictaluri n. sp. This myxozoan parasite is associated with proliferative gill disease in channel catfish Ictalurus punctatus (Rafinesque) in the USA. Specific pathogen free fingerlings were experimentally infected with the actinosporean stage of $H$. ictaluri and necropsied 24, 48, 72, and $96 \mathrm{~h}$ post-infection. At $24 \mathrm{~h}$ post-infection parasite stages were observed primarily in the gastric mucosa and submucosa but were also observed in the skin and buccal cavity. Ovoid organisms were detected in heart and blood vessels of the liver. From 48 to $72 \mathrm{~h}$ after exposure, fewer fluorescent organisms were located in all organs, with the exception of the gills, than were observed at $24 \mathrm{~h}$. These organisms appeared to be degenerating except for those in the gills, which appeared to be multinucleated. By $96 \mathrm{~h}$ post-infection, the organisms could not be detected in fish tissues with the exception of the stages in the gills, which appeared to be a preferred site of development. Throughout the entire $96 \mathrm{~h}$ period of study, no stage of the organism was detected in the brain. Infected tissue sections treated with non-immune rabbit serum and noninfected tissue sections treated with immune rabbit sera all showed negative results by IFAT.
\end{abstract}

KEY WORDS: Proliferative gill disease · PGD ·Aurantiactinomyxon ictaluri $\cdot$ Henneguya ictaluri n. sp. · Myxozoa $\cdot$ Actinosporean $\cdot$ Myxosporean $\cdot$ Polyclonal antibodies

\section{INTRODUCTION}

Proliferative gill disease (PGD), or hamburger gill disease, is associated with high mortalities in commercial channel catfish Ictalurus punctatus (Rafinesque) in the USA. The disease is characterized by branchial inflammation, epithelial hyperplasia, lysis of filamentous cartilages, lamellar fusion, and the presence of myxozoan trophozoites usually in the gills (MacMillan et al. 1989, Burtle et al. 1991, Bellerud et al. 1995).

Several myxosporeans including Henneguya sp. (Bowser et al. 1985), Sphaerospora sp. (Hedrick et al. 1990), and Aurantiactinomyxon sp. (Burtle et al. 1991,

\footnotetext{
*Present address: 01 BP 4626 Ouagadougou 01, Burkina Faso, West Africa

${ }^{* *}$ Corresponding author. E-mail: lpote@cvm.msstate.edu
}

Styer et al. 1991, Pote et al. 1992) had been previously implicated as etiologic agents for PGD. It has since been shown that the life cycle of the PGD organism is similar to other myxozoan life cycles previously described such as that of Myxobolus cerebralis (Markiw \& Wolf 1983, Wolf \& Markiw 1984), Hoferellus carassii (El-Matbouli et al. 1992), Myxobolus arcticus (Kent et al. 1993), Hoferellus carassii (Yokoyama et al. 1993), and Ceratomyxa shasta (Bartholomew et al. 1997), which linked an actinosporean in an aquatic oligochaete with a myxosporean in a fish species. Molecular data have further confirmed that the actinosporean stage and the myxosporean counterparts of $M$. cerebralis (Andree et al. 1997), C. shasta (Bartholomew et al. 1997), Henneguya exilis (Lin et al. 1999), and Tetracapsula bryosalmonae, syn. Tetracapsula renicola n. sp. (Kent et al. 2000), are life stages of single organisms 
(Canning et al. 2000, Okamura et al. 2001). Similarly with PGD, when catfish were exposed to the actinosporean stage, Aurantiactinomyxon spp., isolated from the aquatic oligochaete Dero digitata (Burtle et al. 1991, Styer et al. 1991), PGD organisms were observed in the gills. Based on recent molecular data, it was further shown that the actinosporean stage, A. ictaluri, the PGD myxozoan stages present in the gills, and a subsequent myxosporean gill stage, Henneguya ictaluri n. sp., had identical rRNA gene sequences, thus confirming that the actinosporean, A. ictaluri, is a life stage of the myxosporean, $H$. ictaluri n. sp. (Pote et al. 2000, Hanson et al. 2001)

Although the source of infection causing PGD has been confirmed, the route of infection of Henneguya ictaluri is not clearly understood. Pote \& Waterstrat (1993) showed that the actinosporean Aurantiactinomyxon sp. produced a motile amoeba-like stage upon its exposure to catfish gill filaments. However, in addition to the gills, PGD trophozoites have been shown in liver, head and trunk kidneys, spleen, and brain of naturally infected catfish (MacMillan et al. 1989, Bellerud 1993). El-Matbouli et al. (1999) showed using the triactinomyxon spores of Myxobolus cerebralis that portals of entry into the fish were the secretory openings of the mucous cells in the epidermis, buccal cavity, and gills of rainbow trout. Light and electron microscopy showed the proliferation of this parasite in the epidermis and central nervous system of trout (El-Matbouli et al. 1995). While much is known about the route and course of infection with $M$. cerebralis in trout, very little is known about the point of entry of the actinosporean stage of $H$. ictaluri, the morphology of the early stages in the fish, or the mechanism by which this organism is transported systemically. The purpose of this research was to determine the point of entry of the actinosporean stage of $H$. ictaluri into the catfish and detect the early life stages of this parasite and its dissemination in the channel catfish.

\section{MATERIALS AND METHODS}

Preparation of spores and infection of catfish. Spores of the actinosporean stage of Henneguya ictaluri were prepared according to a modified procedure described by Pote et al. (1994). Briefly, mud was collected from a pond with a confirmed PGD outbreak in the catfish population and rinsed through a screen (300 $\mu \mathrm{m}$ aperture) to remove debris. A dissecting microscope was used to examine material captured on the screen and isolate Dero digitata. Using a modified technique (Yokoyama et al. 1991), worms were placed in sterile water, rinsed with 3 exchanges of sterile water, individually transferred to wells of 96-well plates, and covered with water. The plates were incubated at room temperature until actinosporean spores were released by the infected worms. Those actinosporean spore stages of $H$. ictaluri, Aurantiactinomyxon spp. (Marques 1984, Bellerud 1993, Pote et al. 2000) were concentrated into conical $15 \mathrm{ml}$ polystyrene test tubes and counted.

Specific pathogen free (SPF) channel catfish fingerlings were placed in three $19 \mathrm{l}$ flow through tanks. Twenty fingerlings each were placed in Tanks 1 and 2, and 10 in Tank 3. Before infection the water was lowered in all tanks to a depth of approximately $7.5 \mathrm{~cm}$ and Henneguya ictaluri actinosporean spores were added to Tanks 1 and $2\left(2000\right.$ spores tank $\left.{ }^{-1}\right)$; Tank 3 served as a non-infected control. Six hours later, the water level was raised to fill all tanks and flow through water was continued. At $24,48,72$, and $96 \mathrm{~h}$ post-infection, fish $(\mathrm{n}=5$ each) were collected from Tanks 1 and 2, and a single fish from Tank 3 . All fish were necropsied, and tissues (gills, stomach, intestines, head and trunk kidneys, liver, spleen, heart, skin, muscle, and brain) were collected and placed in neutral buffered $10 \%$ formalin for at least $48 \mathrm{~h}$ before routine histopathology processing. Paraffin-embedded histological sections of all tissues $(4 \mu \mathrm{m}$ thick) were either stained with Mayer's hematoxylin and eosin (H\&E) and examined by light microscopy (100 or $400 \times$ magnification) or deparaffinized, rehydrated, rinsed in distilled water, and used in immunocytochemistry.

Production of polyclonal antiserum and its use in the indirect fluorescent antibody test. Clean spores of the actinosporean stage of Henneguya ictaluri were collected from Dero digitata (Pote et al. 1994) and adjusted to a concentration of $1 \times 10^{5}$ spores $\mathrm{ml}^{-1}$. Polyclonal antibodies to the actinosporean stage of $H$. ictaluri were made as described previously (Belem 1994). Briefly, concentrated $H$. ictaluri spores were sonicated and used as an antigen to immunize a rabbit. The antigen was diluted with sterile distilled water to approximate the delivery of $2 \times 10^{4}$ spores of $H$. ictaluri dose $^{-1}$. Immune and non-immune rabbit sera were adsorbed in live catfish according to a procedure previously described by Belem (1994). Adsorbed and nonadsorbed sera, and non-injected SPF catfish serum were all tested for specificity by indirect fluorescent antibody test (IFAT) on pure Aurantiactinomyxon ictaluri spores and on histopathologically confirmed PGDinfected gill sections.

Polyclonal antibodies were incubated for $30 \mathrm{~min}$ at $37^{\circ} \mathrm{C}$ with air-dried actinosporean spores of Henneguya ictaluri or tissue sections on glass microscope slides, and then fixed in cold acetone for $15 \mathrm{~min}$. Paraffin-embedded tissue sections were deparaffinized, rehydrated, and rinsed in distilled water before use (Haines \& Chelack 1991). Specific antibodies were de- 
tected by using goat fluorescein isothiocyanate (FITC)conjugated anti-rabbit immunoglobulins (Sigma, St. Louis, MO). Washes were done with phosphatebuffered saline (PBS) (0.01 M phosphate and $0.4 \mathrm{M}$ sodium chloride PBS) $\mathrm{pH}$ 8.0. Coverslips were mounted using Vectashield mounting media (Vector Laboratories, Burlingame, CA). Spores and tissue sections were examined and photographed using a Zeiss standard microscope (Carl Zeiss, Oberkochen, West Germany) equipped with an epi-fluorescence condenser and a $100 \mathrm{~W}$ xenon arc lamp.

\section{RESULTS}

Small parasite stages were observed in the mucosa and submucosa of the stomach using IFAT at $24 \mathrm{~h}$ postexposure to the actinosporean spores of Henneguya ictaluri (Fig. 1). Organisms were also seen in the epithelia of the skin and buccal cavity. Ovoid stages were visible in the heart and blood vessels of the liver (Fig. 2). All the gills examined demonstrated the presence of these stages (Fig. 3). Small fluorescent inclusions were often seen in the parenchyma of spleen, and head and trunk kidneys. Amorphous aggregates of very bright fluorescent material were observed in the lumen of the intestines or coating the intestinal epithelia.

From 48 to $72 \mathrm{~h}$ after exposure, stages appeared in the gastric glands of the stomach. Fewer stages were located in the skin and the mouth than were observed at $24 \mathrm{~h}$. Heart and liver blood vessels also showed fewer ovoid forms than were seen at $24 \mathrm{~h}$. The larger stages ap- peared to decrease in the gills with time but the remaining organisms appeared to be larger or degenerating and were located in gill filament stroma along the cartilage. At 72 h, most gills showed very bright fluorescent forms without obvious nuclei. Inclusions in hematopoietic cells of the kidneys and spleen parenchyma were less numerous and the fluorescent intensity had decreased compared with organisms seen at $24 \mathrm{~h}$.

At $96 \mathrm{~h}$ post-exposure, most of the fluorescent organisms had disappeared from the stomach, heart, liver, spleen, and kidneys and only the stages in the stroma of gill filaments were present (Fig. 4). Furthermore, this stage was less numerous but more focally developed. All brains examined were negative during the entire study period. Negative results were obtained by IFAT for all specimens examined with non-immunized rabbit serum and for all non-infected tissue sections.

Histopathology results of tissue sections of all organs and tissues stained with $H \& E$ were negative except for the gills. An organism was first seen at $48 \mathrm{~h}$ after exposure in a single case; the organism appeared to be uninucleated and was located in the stroma of gill filaments. Multinucleated trophozoites were found in the gills at 72 and $96 \mathrm{~h}$ after infection. No organisms were detected with H\&E staining or IFAT in any of the negative control fish.

\section{DISCUSSION}

This experiment showed that IFAT can be used to detect early stages of PGD organisms in infected channel catfish tissues not normally observed by the more

Fig. 1. Fluorescent proliferative gill disease (PGD) organisms in the stomach epithelium of specific pathogen free (SPF) catfish, $24 \mathrm{~h}$ post-exposure to the actinosporean stages of Henneguya ictaluri n. sp. Scale bar $=10 \mu \mathrm{m}$

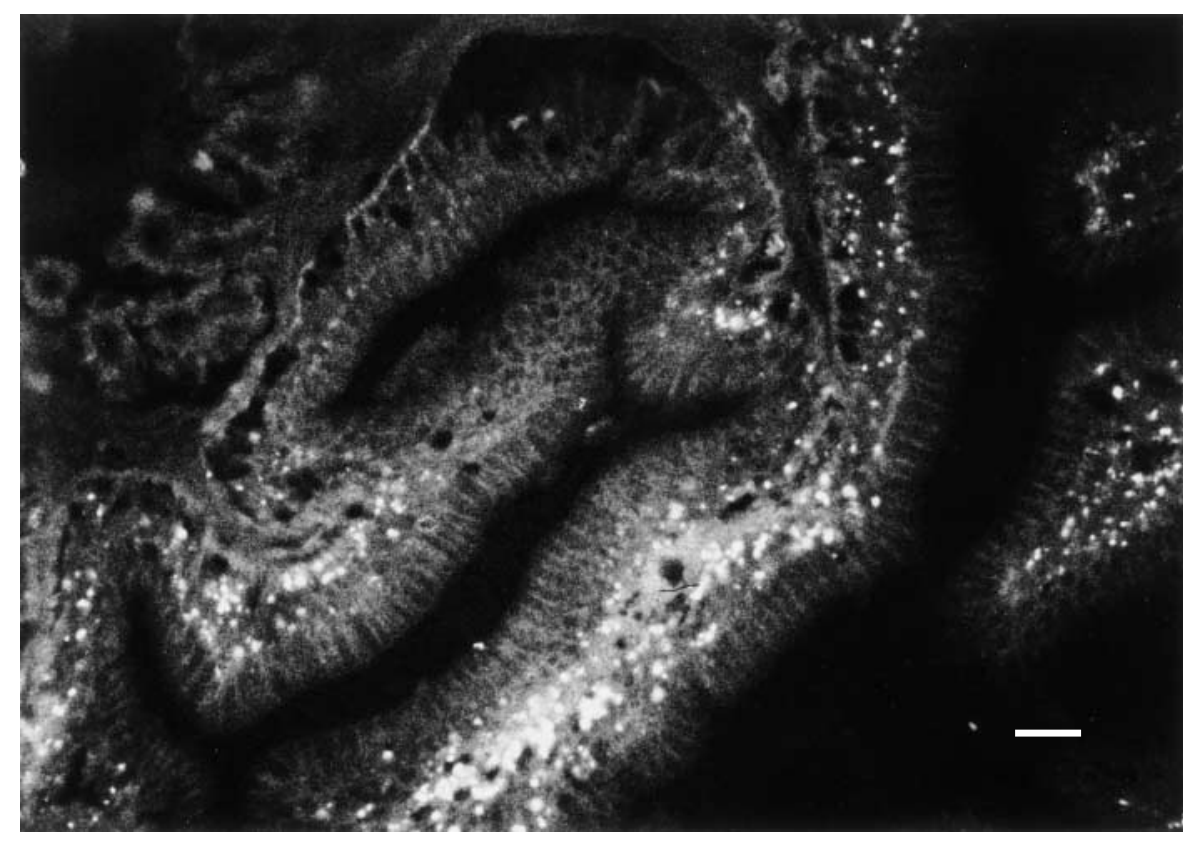




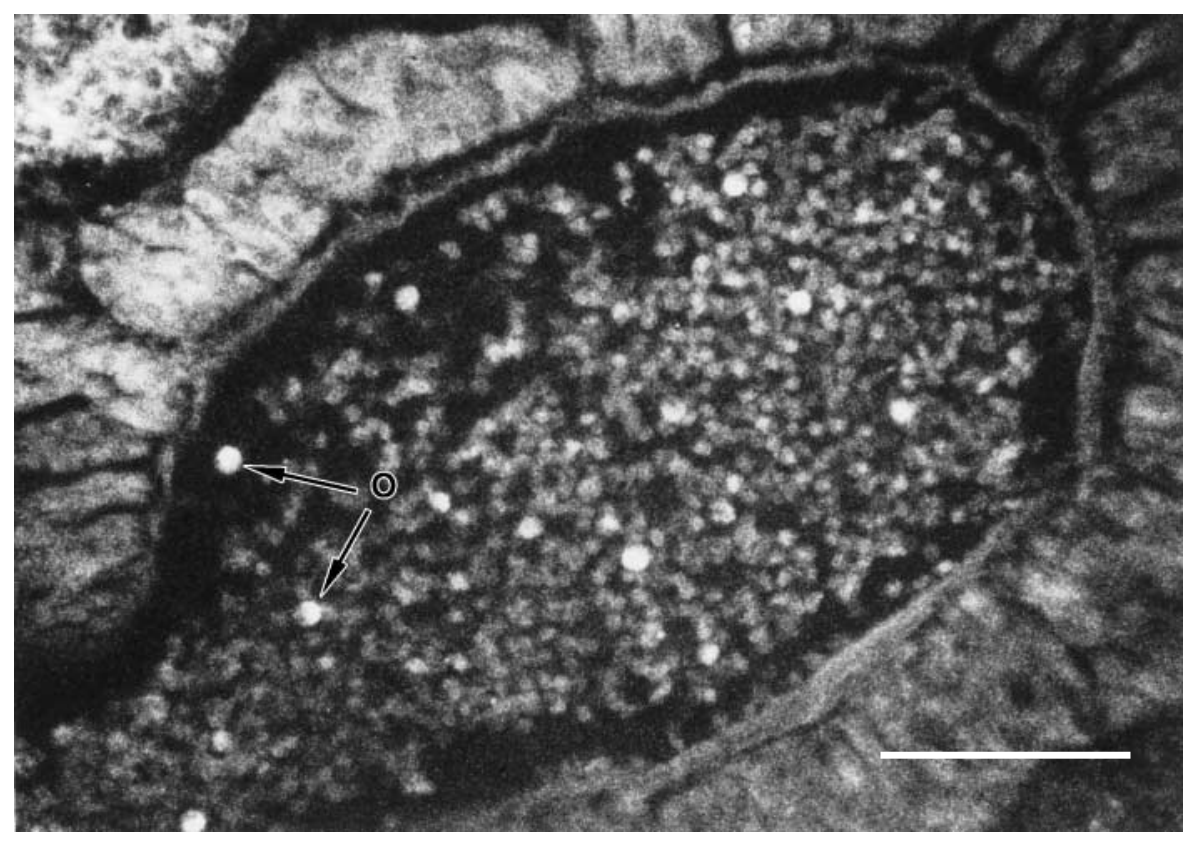

Fig. 2. Fluorescent (PGD) organisms in the liver blood vessel of SPF catfish, $24 \mathrm{~h}$ post-exposure to the actinosporean stage of Henneguya ictaluri. $\mathrm{O}=$ organism. Scale bar = $10 \mu \mathrm{m}$ traditional histopathology methods employing H\&E staining in conjunction with bright field microscopy. With the use of IFAT, organisms were detected $24 \mathrm{~h}$ after infection. Pure actinosporean spores of Henneguya ictaluri and SPF catfish fingerlings were used in this experiment to prevent or reduce the chances of cross-reactivity of the rabbit polyclonal serum with anything other than the PGD organisms. The specificity of the polyclonal serum was further enhanced by adsorption in live catfish. Since organisms were already visible in several locations in the catfish at $24 \mathrm{~h}$ post-infection, future studies should examine what happens to these stages before $24 \mathrm{~h}$ post-exposure. The present study also corroborated the findings that the actinosporean stage of $H$. ictaluri shed by Dero digitata is linked to the PGD organisms observed in catfish gills (Styer et al. 1991, Pote et al. 1992, 2000).

Studies by Pote \& Waterstrat (1993) showed the production of a motile actinosporean stage of Henneguya ictaluri upon exposure to channel catfish gills. Although the mechanism of penetration of the sporoplasm into the host and the role of polar capsules and

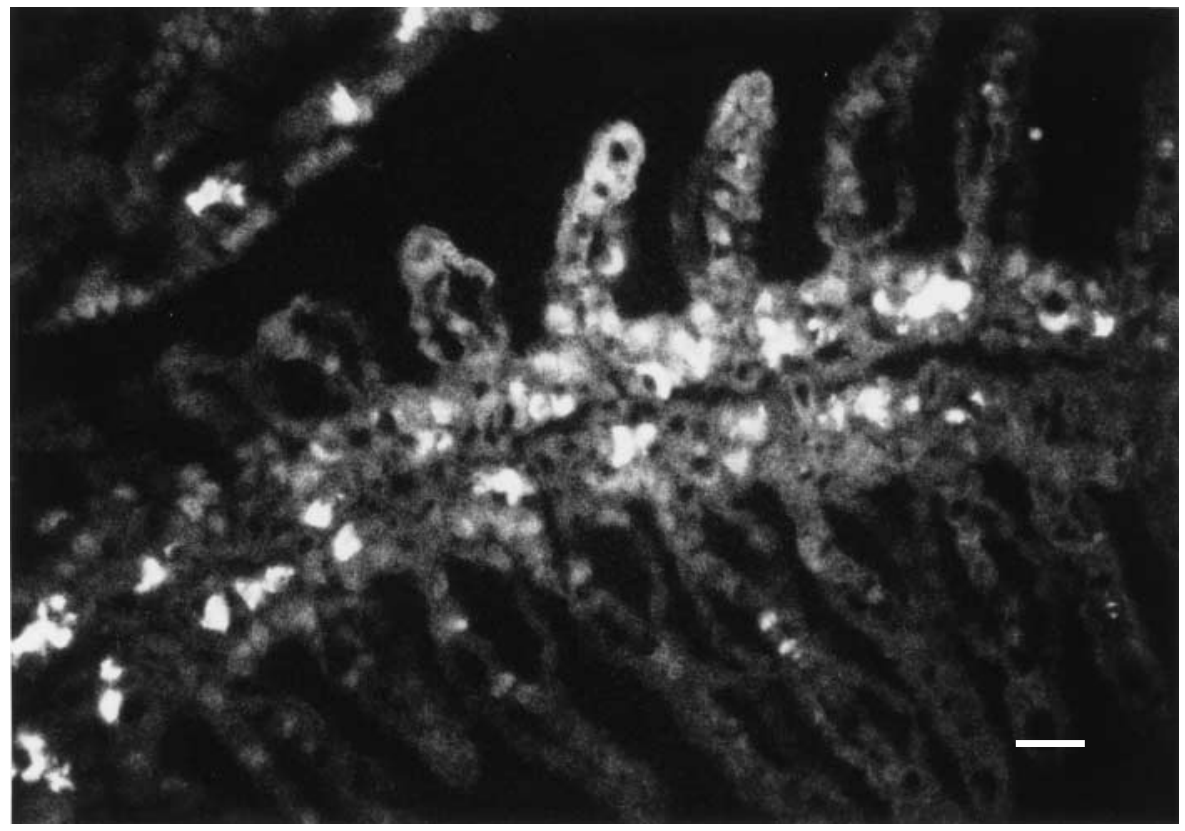

Fig. 3. Fluorescent (PGD) organisms in gills of SPF fish, $24 \mathrm{~h}$ postexposure to the actinosporean stages of Henneguya ictaluri. Scale bar $=10 \mu \mathrm{m}$ 
Fig. 4. Fluorescent (PGD) organisms in gills of SPF fish, $96 \mathrm{~h}$ post-exposure to the actinosporean stages of Henneguya ictaluri. Scale bar = $10 \mu \mathrm{m}$

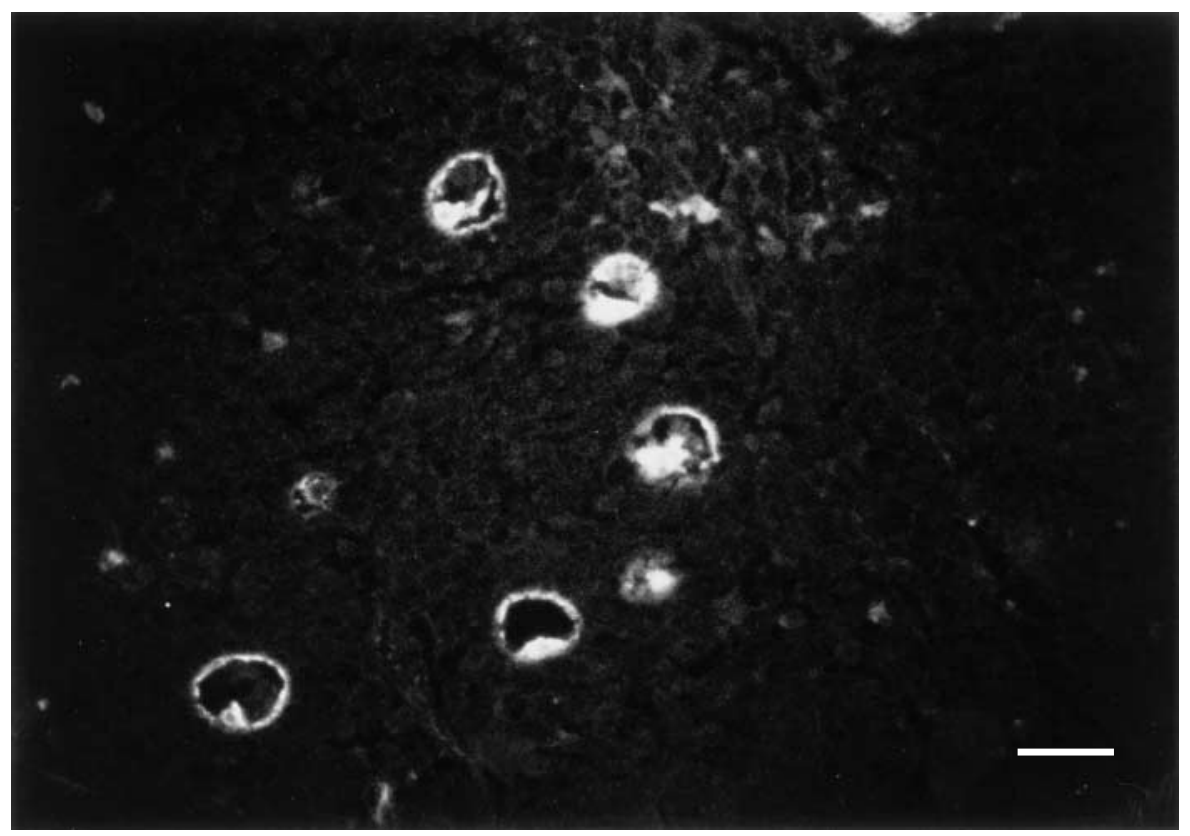

filaments remain unknown, the present study suggests that multiple sites of entry are possible based on the observation of similar fluorescent stages in the skin, the base of the gills, the buccal cavity, and the stomach. This confirmed the work of Yokoyama \& Urawa (1997), who also observed the penetration of Aurantiactinomyxon sp. into the gills of common carp using fluorescent labeling of actinospores; however, they were not able to show skin penetration with this species. The stomach seemed to be an important entry site of the sporozoites as indicated at $24 \mathrm{~h}$. Fluorescent material found in the lumen of the intestines may have been the epispores from actinosporeans in the intestinal tract. This could have indicated that motile stages (Pote \& Waterstrat 1993) were freed upon contact with fish tissues in the stomach and intestinal tract. After penetration into the host tissues, sporozoites of PGD appeared to move or were transported through deeper layers to blood vessels, where they were then transported to the heart. This was evident by the presence of parasite stages in the heart and liver blood vessels in association with red blood cells. Blood circulation could have been responsible for further dissemination of sporozoites to organs such as the spleen, kidneys, liver, and gills, where organisms were found at $24 \mathrm{~h}$ post-exposure. The results of this study are similar to the work by Markiw (1989), which showed multiple portals of entry for a myxozoan, Myxobolus cerebralis, into salmonids.

Organisms were degenerating or decreasing in number at $96 \mathrm{~h}$ in the stomach, skin, liver, spleen, kidneys, and heart. This indicates that these parasitic stages might have been destroyed by the host non- specific defense mechanism (Ellis 1978). The destruction of organisms is most likely explained by the typical inflammatory response and lesions associated with this disease shown in traditional histopathology studies (MacMillan et al. 1989). The gills seemed to be preferred sites of development for the PGD myxosporeans since intact multicellular trophozoites were still observed at $96 \mathrm{~h}$ post-exposure but had degenerated or were non-existent in other organs.

Acknowledgements. The authors thank Drs A. Jerald Ainsworth, Frank W. Austin, Larry Hanson, and William R. Maslin for their technical advice, and Erle Chenney and Judith Hackathorn for their technical support. A.M.G.B. dedicates the publication to the memory of Dr Ed Couvillion, his original major professor, who died during the course of his $\mathrm{PhD}$ program. Research was supported by USDA grant \#32400260121-3590836 and by the College of Veterinary Medicine and the Mississippi Agricultural and Forestry Experiment Station (MAFES). This paper is MAFES publication \#J-9726.

\section{LITERATURE CITED}

Andree KB, Gresoviac SJ, Hedrick RP (1997) Small subunit ribosomal RNA sequences unite alternate actinosporean and myxosporean stages of Myxosoma cerebralis the causative agent of whirling disease in salmonid fish. J Eukaryot Microbiol 44:208-215

Bartholomew JL, Whipple MJ, Stevens DG, Fryer JL (1997) The life cycle of Ceratomyxa shasta, a myxosporean parasite of salmonids, requires a freshwater polychaete as an alternate host. J Parasitol 83:859-868

Belem AMG (1994) Portals of entry of Aurantiactinomyxon ictaluri and increased infection with Aurantiactinomyxon after immunosuppression in channel catfish. $\mathrm{PhD}$ dissertation, Mississippi State University, Mississippi State 
Bellerud BL (1993) Etiological and epidemiological factors affecting outbreaks of proliferative gill disease on Mississippi channel catfish farms. $\mathrm{PhD}$ thesis, Mississippi State University, Starkville

Bellerud BL, Pote LM, Lin TL, Johnson MJ, Boyle CR (1995) Etiological and epidemiological factors associated with outbreaks of proliferative gill disease in channel catfish. J Aquat Anim Health 7:124-131

Bowser PR, Munson AD, Jarboe HH, Stiles FN (1985) Transmission trials of proliferative gill disease in channel catfish (Ictalurus punctatus). Miss Agric For Exp Stn Res Rep 10: $1-4$

Burtle GJ, Harrison LR, Styer EL (1991) Detection of a triactinomyxid myxozoan in an oligochaete from ponds with proliferative gill disease in channel catfish. J Aquat Anim Health 3:281-287

Canning EU, Curry A, Feist S, Longshaw M, Okamura B (2000) A new class and order of myxozoans to accommodate parasites of bryozoans with ultrastructure observations on Tetracapsula bryosalmonae (PKX organism). J Eukaryot Microbiol 47:456-468

Ellis AE (1978) The immunology of teleosts. In: Roberts PJ (ed) Fish pathology. Bailliere Tindall, London, p 92

El-Matbouli M, Fischer-Scherl T, Hoffmann RW (1992) Transmission of Hoferellus carassii Achmerov, 1960 to goldfish Carassius auratus via an aquatic oligochaete. Bull Eur Assoc Fish Pathol 12:54-56

El-Matbouli M, Hoffman RW, Mandok C (1995) Light and electron microscopic observations on the route of the triactinomyxon-sporoplasm of Myxobolus cerebralis from epidermis into rainbow trout cartilage. J Fish Biol 46: 919-935

El-Matbouli M, Hoffmann RW, Schoel H, McDowell TS, Hedrick RP (1999) Whirling disease: host specificity and interaction between the actinosporean stage of Myxobolus cerebralis and rainbow trout Oncorhynchus mykiss. Dis Aquat Org 35:1-12

Haines DM, Chelack BJ (1991) Technical considerations for developing enzyme immunohistochemical staining procedures on formalin-fixed paraffin-embedded tissues for diagnostic pathology. J Vet Diagn Invest 3:101-112

Hanson LA, Lin D, Pote LMW, Shivaji R (2001) Small subunit rRNA gene comparisons of four actinosporean species to establish a polymerase chain reaction test for the causative agent of proliferative gill disease in channel catfish. J Aquat Anim Health 13:117-123

Hedrick RP, McDowell T, Groff JM (1990) Sphaerospora ictaluri sp. (Myxosporea: Sphaerosporidae) observed in the kidney of channel catfish, Ictalurus punctatus Rafinesque. J Protozool 37:107-112

Kent ML, Whitaker DJ, Margolis L (1993) Transmission of Myxobolus arcticus Pugachev and Khokhlov, 1979, a myxosporean parasite of Pacific salmon, via a triactinomyxon from the aquatic oligochaete Stylodrilus heringianus (Lumbriculidae). Can J Zool 71:1207-1211

Kent ML, Khattra J, Hedrick RP, Devlin RH (2000) Tetracapsula renicola n. sp. (Myxozoa: Saccosporidae); the PKX myxozoan-the cause of proliferative kidney disease of salmonid fishes. J Parasitol 86:103-111

Lin DL, Hanson LA, Pote LM (1999) Small subunit ribosomal RNA sequence of Henneguya exilis (Class Myxosporea) identifies the actinosporean stage from an oligochaete host. J Eukaryot Microbiol 46:66-68

MacMillan JR, Wilson CC, Thiyagarajah A (1989) Experimental induction of proliferative gill disease in specificpathogen-free channel catfish. J Aquat Anim Health 1: $245-254$

Markiw ME (1989) Portals of entry for salmonid whirling disease in rainbow trout. Dis Aquat Org 6:7-10

Markiw ME, Wolf K (1983) Myxosoma cerebralis (Myxozoa: Myxosporea) etiologic agent of salmonid whirling disease requires tubificid worm (Annelida: Oligochaeta) in its life cycle. J Protozool 30:561-564

Marquès A (1984) Contribution à la connaissance des actinomyxidies: ultrastructure, cycle biologique, systématique. Thèse de Doctorat d'Etat, Université des Sciences et Techniques du Languedoc, Montpellier

Okamura B, Anderson CL, Longshaw M, Feist S, Canning E (2001) Patterns of occurrence and 18s rDNA sequence variation of PKX (Tetracapsula bryosalmonae), the causative agent of salmonid proliferative kidney disease. J Parasitol 87:379-385

Pote LM, Waterstrat P (1993) Motile stage of Aurantiactinomyxon sp. (Actinosporea: Triactinomyxidae) isolated from Dero digitata found in channel catfish ponds during outbreaks of proliferative gill disease. J Aquat Anim Health 5:213-218

Pote LM, Chenney EF, Lin TL, Hackathorn JA (1992) Experimental transmission of proliferative gill disease (PGD) in channel catfish after exposure to actinosporea released by Dero sp. isolated from a pond during an outbreak of PGD. 45th Annual Meeting of Animal Disease Research Workers in Southern States, MS. March 29-30, Mississippi State, MS

Pote LM, Bellerud B, Lin TL, Chenney EF (1994) The isolation and propagation of Dero digitata infected with Aurantiactinomyxon sp. J World Aquat Soc 25:303-307

Pote LM, Hanson LA, Shivaji R (2000) Small subunit rRNA sequences link proliferative gill disease in channel catfish to Henneguya n. sp. (Myxozoa: Myxosporea). J Aquat Anim Health 12:230-240

Styer EL, Harrison LR, Burtle GJ (1991) Experimental production of proliferative gill disease in channel catfish exposed to myxozoan-infected oligochaete, Dero digitata. J Aquat Anim Health 3:288-291

Wolf K, Markiw ME (1984) Biology contravenes taxonomy in the Myxozoa: new discoveries show alternation of invertebrate and vertebrate hosts. Science 225:1449-1452

Yokoyama H, Urawa S (1997) Fluorescent labeling of actinospores for determining the portals of entry into fish. Dis Aquat Org 30:165-169

Yokoyama HK, Ogawa K, Wakabayashi H (1991) A new collection method of actinosporeans: a probable infective stage of myxosporeans to fishes from tubificids and experimental infection of goldfish with the actinosporean Raabeia sp. Gyobyo Kenkyu 26:133-138

Yokoyama H, Ogawa K, Wakabayashi H (1993) Involvement of Branchiura sowerbyi (Oligochaeta: Annelida) in the transmission of Hoferellus carassii (Myxosporea: Myxozoa) the causative agent of kidney enlargement disease (KED) in goldfish Carassius auratus. Gyobyo Kenkyu 28: 135-139

Submitted: July 31, 2000; Accepted: August 1, 2001

Proofs received from author(s): December 5, 2001
Editorial responsibility: Wolfgang Körting,

Hannover, Germany 